\title{
Efforts to Improve Rhythmic Gymnastics Learning Outcomes Through The Audio Visual Media
}

\author{
Rizky Puspa Sari \\ Physical Education, Post Graduate \\ Program \\ Universitas Negeri Medan \\ Medan, Indonesia \\ rizkypuspa94@gmail.com
}

\author{
Amir Supriadi \\ Physical Education, Post Graduate \\ Program \\ Universitas Negeri Medan \\ Medan, Indonesia
}

\author{
Nurkadri \\ Physical Education, Post Graduate \\ Program \\ Universitas Negeri Medan \\ Medan, Indonesia
}

\begin{abstract}
The purpose of this study was to determine the increase in rhythmic gymnastics learning outcomes through audio-visual media. The method used is CAR (Classroom Action Research). CAR has two cycles, namely in the first cycle making action plans, carrying out actions, observations and reflections. The results of reflection are used as a basis for the planning phase of the second cycle if the first cycle is not successful. So in the second cycle gives more learning through Audio Visual Media and gives more direction to students where errors are often more guided while in class before going back to practice in the field. The research instrument uses a portfolio and observation sheets. Data analysis techniques use percentages. The conclusion that through audio-visual media can improve rhythmic gymnastics learning outcomes.
\end{abstract} Visual

Keywords - Learning Outcomes, Rhythmic Gymnastics, Audio

\section{INTRODUCTION}

According to Supandi (1992: 1) "Physical education is a process of systematic interaction between students and the environment that is managed through effective and efficient physical development towards the formation of a complete human being". Physical education, sports, and health are media to encourage physical growth, psychological development, motor skills, knowledge and reasoning, appreciation of values (attitude-mental-emotionalsportsmanship-spiritual-social), and habituation of healthy lifestyles that lead to stimulate the growth and development of a balanced physical and psychological quality.

Suwarjo, et al (2009). Rhythmic gymnastics is gymnastics accompanied by musical rhythms, songs, or beats and prioritizes harmony in motion. Rhythmic gymnastics should follow the rhythm that accompanies it. Rhythmic gymnastics is a blend of dance and sports movements.

The results of the researchers' initial observation interview regarding student learning outcomes in gymnastics lessons, apparently there are still many low grades. It was proven that there were still many students who did not understand how to do the right rhythmic gymnastic movements. Researchers do the learning process through audio-visual media in the form of movie shows (videos) or in the form of music used. This can encourage solving problems in doing rhythmic gymnastic movements.

Purwanto (2008: 46), learning outcomes represent the achievement of educational goals in students who take part in the teaching and learning process. Learning outcomes are actual, meaning that the realization of educational goals is achieved, so the learning outcomes measured are highly dependent on the educational objectives. Husdarta and Saputra (2000: 4) suggest that the main task of the teacher is to create a climate or atmosphere so that the learning process takes place in the classroom. In the field, the main characteristic of the learning process is that students can be actively involved in the learning process. Teachers must always strive so students are motivated to play more roles. Nevertheless the teacher still functions as a manager of the learning and learning process.

To support the implementation of learning in school, the creativity of a teacher is needed, so that the learning process can provide a good learning experience in full to students. This phenomenon is a problem due to the lack of ability of an education teacher to take advantage of his role as a teacher who has potential in accordance with the demands of curriculum targets and absorption and as creative educators in activating physical education learning in schools. The formulation of the problem of this research is how to improve rhythmic gymnastics learning outcomes through audio-visual media and know the Improvement of Rhythmic Gymnastics Learning Outcomes through the Audio Visual Media.

\section{METHOD}

Researchers use the Classroom Action Research (CAR) method or Classroom Action Research. The action is given by the teacher or with direction from the teacher done by students. 


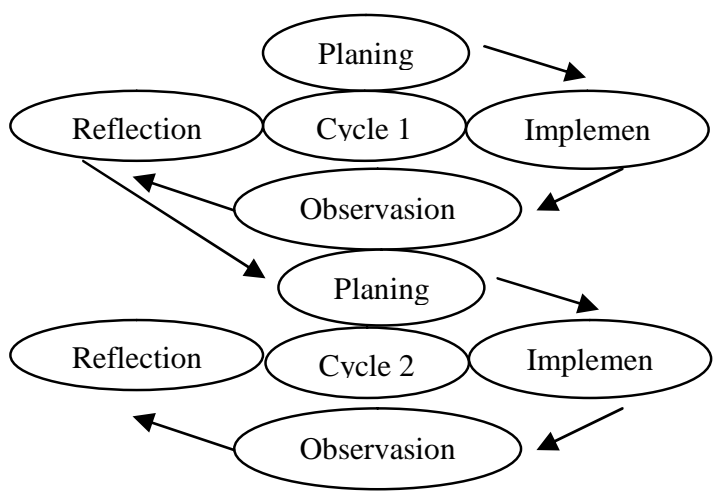

Fig. 1. Cycle Scheme in Classroom Action Research Source: Arikunto, et al (2009: 16)

The subjects of the study were all students of class V 106160 Tanjung Rejo State Primary School 2016/2017 Academic Year with a total of 27 students. Tools used in the room / field, tape / laptop, cd, speaker, whistle, assessment format.

\section{RESULTS AND DISCUSSION}

The results of research on efforts to improve rhythmic gymnastics learning outcomes through audio-visual media can be seen in the following picture:

TABLE1. DIFFERENCES IN RHYTHMIC GYMNASTICS LEARNING OUTCOMES

\begin{tabular}{|c|c|c|c|c|c|}
\hline \multirow{2}{*}{ No } & \multirow{2}{*}{ Information } & \multicolumn{2}{|c|}{ Complete } & \multicolumn{2}{c|}{ Not Complate } \\
\cline { 3 - 6 } & & Amount & Percentage & Amount & Percentage \\
\hline 1. & Preliminary & 10 & $37,03 \%$ & 17 & $62,96 \%$ \\
\hline 2. & Cycle I & 16 & $59,25 \%$ & 11 & $40,74 \%$ \\
\hline 3. & Cycle II & 22 & $81,48 \%$ & 5 & $18,51 \%$ \\
\hline
\end{tabular}

Based on preliminary data, that the ability of students in rhythmic gymnastics learning is still relatively low. Of the 27 students who were sampled in this study, it turns out that only 10 students (37.03\%) have mastery learning, while the remaining 17 people $(62.96 \%)$ students have not reached mastery learning. On the results of the first cycle test of 27 students there were 16 students $(59.25 \%)$ who had gotten the level of completeness, while 11 students $(40.74 \%)$ had not reached the level of mastery learning. The percentage value of completeness of the minimum average grade obtained only reached $72.11 \%$. While the results of the second cycle test obtained 22 students $(81.48 \%)$ have achieved mastery learning while 5 students $(18.51 \%)$ who have not met mastery learning. The average grade obtained reached $(81.85 \%)$. The implementation in this second cycle, in general, went well and was conducive, because the completeness of classical learning $(81.85 \%)$ had been achieved so rhythmic gymnastics learning through audio-visual media stopped.

The following is a discussion of the results above:

1) Results of Rhythmic Gymnastics Learning Activities carried out by the Teacher

- In arranging the class the teacher is good

- Guidance given by teachers to students is evenly distributed

- The teacher evaluates movements that were previously difficult for students to make

- Teacher's skills in using media are good

2) Results of Rhythmic Gymnastics Learning Activities carried out by Students

- High curiosity of the continuation of the material

- Have discussions according to the worksheet

- Already understand about things that have not been understood before

- When the attitude of implementing a movement that was difficult to do before, namely the stretching and core movements, was well done

3) Reflection

Based on the results of the observation, the following is described the failure and success in implementing the actions in the second cycle, namely:

1. Most students are able to do rhythmic gymnastics

2. Students' knowledge in rhythmic gymnastics learning has expanded.

3. The teacher has been able to motivate students to be active in teaching.

4. Involvement of student activities in doing movements is good.

5. On the attitude of the implementation of the stretching and core movements are very well done.

6. During the learning progress the student activity has increased.

\section{CONCLUSION}

An increase in rhythmic gymnastics learning outcomes through audio visual media.

\section{REFERENCES}

[1] Supandi, 1992, Teaching and Learning Strategies of Physical Education and Sports. Jakarta: Ministry of Education and Culture.

[2] Suwarjo, et al 2009, Physical Education, Sports, and Health for Elementary / Primary Schools V, Semarang: Erlangga.

[3] Purwanto, 2008, Evaluation of Learning Outcomes. Surakarta: Learning Library.

[4] Husdarta and Saputra, 2000, Learning and Learning. Bandung: DEPDIKNAS.

[5] Arikunto, Suhardjono, Supardi. 2010. Classroom Action Research Jakarta: PT. Earth Aksara. 